Analisis Unsur Sosio-Psikologis.... (Muhamad Munawir)

\title{
ANALISIS UNSUR SOSIO-PSIKOLOGIS SASTRA PUISI DOA UNTUK ANAK CUCU KARYA W.S. RENDRA SEBAGAI SUMBER PEMBELAJARAN SASTRA
}

\author{
Oleh: Muhamad Munawir \\ (Guru MTS Mifahul Ulum Telang Karya) \\ Email: muhamadmunawir899@gmail.com
}

\begin{abstract}
Abstrak
Puisi adalah salah satu karya sastra yang lahir dari cerminan kehidupan sosial budaya masyarakat pada saat puisi dilahirkan den merupakan bentuk ekspresi curahan hati seorang penyair. Oleh karena itu, kesulitan yang sering muncul dalam menghadapi puisi adalah kesulitan memahami maksud dari puisi itu sendiri. Berdasarkan hal tersebut maka masalah dalam penelitian ini adalah bagaimanakah unsur sosiopsikologis sastra yang terdapat dalam kumpulan puisi Doa untuk Anak Cucu karya W.S.Rendra. tujuan penelitian ini untuk mengetahui dan mendeskripsikan unsur sosiopsikologis sastra yang terdapat dalam kumpulan puisi Doa untuk Anak Cucu karya W.S. Rendra. Metode penelitian yang digunakan adalah metode metode penelitian kualitatif deskriptif. Hasil penelitian menunjukkan bahwa kumpulan puisi Doa untuk Anak Cucu karya W.S. Rendra terdapat unsur sosiopsikologis sastra yang meliputi hubungan antara kehidupan sosial masyarakat dengan gagasan salam suatu puisi, unsur kehidupan sosial masyarakat dalam puisi dan sikap penyair terhadap kehidupan sosial masyarakatnya.
\end{abstract}

Kata Kunci: Puisi, Sosio-Psikologi Sastra

\section{ANALYSIS OF SOCIO-PSYCHOLOGICAL ELEMENTS OF POETRY PRAYER FOR CHILDREN'S CUCU CARYA W.S. RENDRA AS A SOURCE OF LEARNING LITERATURE}

\begin{abstract}
Poetry is one of the literary works born from the reflection of the social life of the society when poetry is born and is a form of expression of the poetry of a poet's heart. Therefore, the difficulty that often arises in the face of poetry is the difficulty of understanding the purpose of the poem itself. Based on this, the problem in this study is how the elements of sociopsychological literature contained in a collection of poetry Doa untuk Anak Cucu by W.S.Rendra. the purpose of this study was to find out and describe the sociopsychological elements of literature contained in a collection of Prayer poems for the Grandchildren by W.S. Rendra. The research method used is a descriptive qualitative research method. The results of the study show that a collection of Prayer poems for posterity by W.S Rendra has a sociopsychological element of literature which includes the relationship between the social life of the community and the idea of
\end{abstract}


greeting a poem, elements of social life in poetry and the poet's attitude towards the social life of his community.

Keywords: Poetry, Sociopsychology of Literature

\section{A. PENDAHULUAN}

Karya sastra merupakan sebuah cerita yang menampilkan hasil kreasi pengarang. Wujud dari karya sastra berupa kata-kata. Dengan demikian karya sastra menampilkan dunia dalam kata dan menampilakan dunia dalam kemungkinan-kemungkinan dan sastra berbicara tentang kehidupan, sehingga dalam karya sastra terdapat makna tentu tentang kehidupan yang isinya perlu dicerna secara mendalam oleh pembaca (Wardani, 2009:1).

Salah satu karya sastra yang yang estetik dan kaya makna adalah puisi. Puisi merupakan salah satu bentuk karya sastra yang menggunakan kata-kata indah dan kaya makna, pemadatan segala unsur kekuatan bahasa, berisi ungkapan pikiran perasaan penyair dan latar belakang penyair itu sendiri (Samosie, 2015:5).

Penyair menciptakan sebuah puisi biasanya didasarkan pada latar belakang sosial budaya yang dilihat ataupun dialaminya. Hal tersebut erat kaitanya dengan kehidupan sosialmasyarakat yang memberikan inspirasi pada penyair untuk menuangkan kedalam puisi. Istilah sosial dapat diartikan sebagai hubungan manusia di dalam masyarakat, misalnya berbagai masalah yang sedang dihadapi oleh masyarakat misalnya dalam bidang kesejahteraan kemudian dalam hal psikologi, penyair mengungkapkan gejolak jiwanya atau pantulan kejiwaan yang menggunakan cipta, rasa dan karya yang berhubungan dengan unsur sosiopsikologis sastra.

Aminuddin (2013:186) menjelaskan bahwa pendekatan sosiopsikologis sastra adalah suatu pendekatan yang berusaha memahami latar belakang kehidupan sosial masyarakat yang memengaruhi terwujudnya gagasan dalam puisi, terwujudnya gagasan tentang kehidupan sosial masyarakat dalam puisi dan memahami sikap pengarang terhadap kehidupan sosial masyarakat yang dipaparkannya. 
Pada kumpulan puisi Doa untuk Anak Cucu karya W.S. Rendra penyair menceritakan keadaan masyarakat dan harapannya pada masa itu lewat pusi. Alasan penulis melakukan penelitian terhadap kumpulan puisi ini karena terdapat banyak unsur sosiopsikologis sastra yang di dalamnya terdapat hubungan sosial masyarakat, tanggapan kejiwaan atau sikap pengarang terhadapa lingkungan dan gagasan tentang kehidupan sosial masyarakat. Aminuddin (2013:186-192) mengatakan bahwa unsur sosiopsikologis sastra terbagi menjadi tiga bagian yaitu hubungan antara kehidupan sosial masyarakat dengan gagasan dalam puisi, unsur kehidupan sosial masyarakat dalam puisi serta sikap penyair terhadap corak kehidupan sosial masyarakatnya.

Hubungan antara kehidupan sosial masyarakat dengan gagasan dalam suatu puisi adalah terjalin adanya hubungan timbal balik. Yang dimaksud dengan hubungan timbal balik itu adalah penyair dapat mengangkat sosial kehidupan masyarakat sebagai bahan penciptaan dan puisi yang diciptakan mampu menggambarkan kembali kehidupan sosial masyarakat kepada pembaca, serta memberikan sikap atau penilaian terhadapnya. Adanya saling pengaruh antara kehidupan sosial masyarakat dengan terwujudnya gagasan dalam suatu puisi itu sesuai dengan realitas keberadaan penyair itu sendiri. Sebagai manusia, penyair adalah anggota suatu kelompok kehidupan sosial masyarakat. Ia dipengaruhi oleh kehidupan sosial masyarakat yang menjadi lingkungan kehidupannya. Akan tetapi sebagai individu, penyair juga menampilkan sikap penilaian terhadap sesuatu corak kehidupan sosial masyarakat.

Unsur kehidupan sosial masyarakat dalam puisi adalah kehidupan sosial masyarakat, baik itu secara individu maupun kelompok, dapat menjadi bahan penciptaan suatu puisi. Corak kehidupan sosial masyarakat yang diangkat menjadi bahan penciptaan itu dapat beraneka ragam. Hal tersebut berupa adat kebiasaan, pandangan hidup, maupun perilaku suatu masyarakat yang tidak ada hubungannya dengan masalah politik, tetapi berhubungan dengan masalah kehidupan sosial.

Sikap penyair terhadap corak kehidupan sosial masyarakatnya dapat berupa sikap keikhlasan, masa bodoh, tidak setuju serta berbagai macam sikap lainnya sesuai dengan kompleksitas pikiran penyair itu sendiri. 
Perumusan masalah dalam penelitian ini adalah bagaimanakah unsur sosiopsikologis sastra pada kumpulan puisi Doa untuk Anak Cucu karya W.S. Rendra dan tujuan pada penelitian ini adalah untuk mengetahui dan mendeskripsikan unsur sosiopsikogis sastra kumpulan puisi Doa untuk Anak Cucu karya W.S. Rendra. Penelitian ini memiliki manfaat diantaranya dapat dijadikan referensi untuk analisis penelitian unsur sosiopsikologis sastra.

Salah satu unsur yang terkandung dalam puisi adalah unsur kehidupan sosial budaya serta ragam sikap penyair terhadapnya. Dalam hal ini pendekatan yang dapat diguakan adalah pendekatan sosiopsikologis yang meliputi hubungan antara kehidupan sosial masyarkat dengan gagasan dalam suatu puisi, unsur kehidupan sosial masyarakat dalam puisi dan sikap penyair terhadap corak kehidupan sosial masyarakat (Aminuddin, 2013:186).

\section{Hubungan antara Kehidupan Sosial Masyarakat dengan Gagasan dalam Suatu Puisi}

Hubungan antara kehidupan sosial masyarakat dengan gagasan dalam suatu puisi terjalin adanya hubungan timbal balik. Yang dimaksud dengan hubungan timbal balik itu adalah penyair dapat mengangkat sosial kehidupan masyarakat sebagai bahan penciptaan dan puisi yang diciptakan mampu menggambarkan kembali kehidupan sosial masyarakat kepada pembaca, serta memberikan sikap atau penilaian terhadapnya. Adanya saling pengaruh antara kehidupan sosial masyarakat dengan terwujudnya gagasan dalam suatu puisi itu sesuai dengan realitas keberadaan penyair itu sendiri. Sebagai manusia, penyair adalah anggota suatu kelompok kehidupan sosial masyarakat. Ia dipengaruhi oleh kehidupan sosial masyarakat yang menjadi lingkungan kehidupannya. Akan tetapi sebagai individu, penyair juga menampilkan sikap penilaian terhadap sesuatu corak kehidupan sosial masyarakat.

\section{Unsur Kehidupan Sosial Masyarakat dalam Puisi}

Kehidupan sosial masyarakat, baik itu secara individu maupun kelompok, dapat menjadi bahan penciptaan suatu puisi. Corak kehidupan sosial masyarakat yang diangkat menjadi bahan penciptaan itu dapat beraneka ragam. Hal tersebut berupa adat kebiasaan, pandangan hidup, maupun perilaku suatu masyarakat yang 
tidak ada hubungannya dengan masalah politik, tetapi berhubungan dengan masalah kehidupan sosial.

\section{Sikap Penyair terhadap Corak Kehidupan Sosial Masyarakatnya}

Tentang sikap seorang penyair terhadap corak kehidupan sosial masyarakat dapat berupa sikap keikhlasan, masa bodoh, tidak setuju serta berbagai macam sikap lainnya sesuai dengan kompleksitas pikiran penyair itu sendiri.

Penelitian tentang sosiopsikologis dalam karya sastra pernah dilakukan oleh Marhama, mahasiswa Fakultas Keguruan dan Ilmu Pendidikan (FKIP), Program Studi Pendidikan Bahasa dan Satra Indonesia, Universitas Persatuan Guru Republik Indonesia (PGRI) Palembang, tahun 2008 dengan judul skripsi “Analisis unsur sosiopsikologi dalam kumpulan puisi Kaca Jendela karya Febe Sevtin Rahmawati". Berdasarakan hasil penelitian yang telah dilakukan oleh Marhama terdapat unsur sosiopsikologis, yang meliputi hubungan antara kehidupan sosial masyarakat dengan gagasan dalam suatu puisi yang mengangkat kehidupan sosial masyarakat sebagai bahan penciptaan dan puisi yang diciptakan mampu memberikan gambaran kehidupan sosial masyarakat kepada pembaca. Kemudian unsur kehidupan sosial masyarakat dalam puisi berupa adat kebiasaan, pandangan hidup dan perilaku masyarakat. Selanjutnya sikap penyair terhadap corak kehidupan sosial masyarakat tentang sikap keikhlasan, masa bodoh, tidak setuju dan sikap peduli.

\section{B. METODOLOGI PENELITIAN}

Penelitian ini metode penelitian yang digunakan adalah metode kualitatif deskriptif untuk menganalisis unsur sosiopsikologis sastra kumpulan puisi Doa untuk Anak Сиси karya W.S. Rendra. Suryabrata (2015:75-77) mengatakan bahwa metode deskriptif adalah penelitian yang bermaksud untuk membuat pencandraan (deskripsi) mengenai situasi-situasi atau kejadian-kejadian.

Penelitian ini tentunya dibutuhkan sebuah data dan sumber data yang akan dijadikan bahan penelitian. Siswantoro (2010:70) data adalah sumber informasi yang akan diseleksi sebagai bahan analisis. Data yang digunakan dalam penelitian ini adalah kumpulan puisi Doa untuk Anak Cucu karya W.S. Rendrayang terdapat 
22 judul puisi. Namun dalam menganalisis kumpulan puisi ini yang akan dianalisis adalah beberapa puisi yang mengandung unsur sosiopsikologis sastra yang berjumlah 10 puisi. Adapun judul puisi yang akan dianalisis adalah "Inilah Saatnya, Kesaksiaan tentng Mastodon-mastodon, Sajak Bulan Mei 1998 di Indonesia, Ibu di atas Debu, Pertanyaan Penting, Politisi itu Adalah, He, Remco, Kesaksian Akhir Abad, Sagu Ambon, Dimana Kmu, De 'Na?, Maskumambang”.

Teknik pengumpulan data merupakan langkah yang paling strategis dalam penelitian, karena tujuan utama dalam penelitian adalah mendapatkan data. Tanpa mengetahui teknik pengumpulan data, maka peneliti tidak akan mendapatkan data yang memenuhi standar data yang ditetapkan (Sugiyono, 2009:224). Teknik yang digunakan untuk mengumpulkan data dalam penelitian ini adalah teknik dokumentasi. Berdasarkan pernyataan tersebut, dokumen yang digunakan dalam penelitian ini adalah mencari buku yang berkaitan dengan sosiopsikologi sastra, buku-buku penelitian sastra dan buku kumpulan puisi Doa untuk Anak Cucu karya W.S. Rendra.

Teknik analisis data yang digunakan untuk menganalisis data pada penelitian ini adalah teknik analisis konten. Analisis isi (content analysis) menurut Vredenbreght (dikutip Ratna, 2010:357) berkaitan dengan (isi) komunikasi. Komunikasi itu sendiri paling sedikit melibatkan tiga komponen dengan fungsinya masing-masing, yaitu: a) siapa yang berbicara, b) apa yang dibicarakan dan c) efek apa yang diakibatkannya. Di antara ketiga komponen yang terpenting adalah komponen kedua, 'apa' isi komunikasi tersebut. Bentuk komunikasi meliputi komunikasi lisan maupun tulisan, baik verbal maupun nonverbal seperti: karya seni, karya sastra, arsitektur, pakaian, alat-alat rumah tangga, termasuk media komunikasi massa seperti film dan televisi.

Dalam kaitannya dengan penelitian ini, teknik analisis konten digunakan untuk mengungkapkan bagaimana unsur sosiopsikologis yang meliputi hubungan antara kehidupan sosial masyarakat dengan gagasan dalam suatu puisi, unsur kehidupan sosial masyarakat dalam puisi dan sikap penyair terhadap corak kehidupan sosial masyarakat pada kumpulan puisi Doa untuk Anak Cucu karya W.S. Rendra. 
Analisis Unsur Sosio-Psikologis.... (Muhamad Munawir)

\section{HASIL PENELITIAN DAN PEMBAHASAN}

Fokus pembahasan dalam penelitian ini adalah untuk mengetahaui dan mendeskripsikan unsur sosiopsikologis sastra kumpulan puisi Doa untuk Anak Сиси karya W.S. Rendra yang meliputi hubungan antara kehidupan sosial masyarakat dengan gagasan dalam suatu puisi, unsur kehidupan sosial masyarakat dalam pusi dan sikap penyair terhadap corak kehidupan sosial masyarakatnya.

Buku kumpulan pusi Doa untuk Anak Cucu karya W.S. Rendra berjumlah 22 puisi. Adapun data yang diambil oleh peneliti sebanyak 10 puisi yang mengandung unsur sosiopsikologis sastra diantaranya "Inilah Saatnya, Kesaksiaan tentng Mastodon-mastodon, Sajak Bulan Mei 1998 di Indonesia, Ibu di atas Debu, Pertanyaan Penting, Politisi itu Adalah, He, Remco, Kesaksian Akhir Abad, Sagu Ambon, Dimana Kmu, De 'Na?, Maskumambang”.

Berdasarkan data yang diperoleh peneliti melalui proses analisis buku kumpulan puisi Doa untuk Anak Cucu karya W.S. Rendra, terdapat beberapa puisi yang memiliki dan tergolong pada tiga unsur sosiopsikologis sastra. Ketiga unsur tersebut yaitu: (1) hubungan antara kehidupan sosial masyarakat dengan gagasan dalam suatu puisi, (2) unsur kehidupan sosial masyarakat dalam puisi (3) sikap penyair terhadap corak kehidupan sosial masyarakat.

Ditinjau dari hasil penelitian Marhama, mahasiswa Fakultas Keguruan dan Ilmu Pendidikan (FKIP), Program Studi Pendidikan Bahasa dan Satra Indonesia, Universitas Persatuan Guru Republik Indonesia (PGRI) Palembang, tahun 2008 dengan judul skripsi “Analisis unsur sosiopsikologi dalam kumpulan puisi Kaca Jendela karya Febe Sevtin Rahmawati". Penelitian sebelumnya terdapat 7 puisi yang memiliki tiga unsur sosiopsikologis sastra. Penelitian yang sekarang terdapat 10 puisi yang memiliki tiga unsur sosiopsikologis.

Kumpulan puisi Doa untuk Anak Сисu karya W.S. Rendra merupakan curahan hati seorang penyair terntang apa yang pernah ia lihat dan di alami pada masa itu untuk kemudian di tuangkan dalam bentuk puisi. Maka didapatlah unsur kehidupan sosial masyarakat dengan gagasan dalam puisi yang merupakan hubungan timbal balik puisi, maksudnya penyair mengangkat kehidupan sosial 
masyarakat sebagai bahan penciptaan puisi yang berhubungan dengan corak kehidupan sosial yang beragam misalnya adat kebiasaan, pandangan hidup dan lain-lain serta memberikan sikap terhadap corak kehidupan sosial itu sendiri. Kumpulan puisi Doa untuk Anak Cucu karya W.S Rendra menceritakan gambaran kehidupan masyarakat Indonesia seperti penuntutan keadilan, kesengsaraan, perselisihan perdapat sertamasalah ekonomi. Maka dalam kumpulan puisi tersebut penyair menyampaikan harapan dan doanya untuk negerinya supaya generasi masa depan harus lebih baik lagi dalam membangun tanah airnya.

Penelitian yang dilakukan peneliti bertujuan untuk mengetahui puisi-puisi karya W.S Rendra dalam kumpulan puisi Doa untuk Anak Cucu memiliki keterkaitan tiga unsur sosiopsikologis sastra. Ketiga unsur tersebut mampu membantu pembaca dalam mengamati dan merasakan peristiwa apa yang ada dalam puisi dan gambaran kehidupan yang ada dalam puisi tersebut.

Dalam penelitian ini, unsur pertama yaitu hubungan antara kehidupan sosial masyarakat dengan gagasan dalam suatu puisi mampu mengajak pembaca melihat dan merasakan gambaran kehidupan yang di sampaikan oleh penyair lewat puisinya. Unsur yang kedua yaitu unsur kehidupan sosial masyarakat dalam puisi bertujuan bahwa unsur kehidupan sosial dapat menjadi bahan penciptaan suatu puisi, corak kehidupan sosial masyarakat yang diangkat misalnya adat kebiasaan, pandangan hidup maupun perilaku masyarakat yang tidak ada hubungannya dengan masalah politik tetapi lebih berhubungan dengan masalah kehidupan sosial dan unsur terakhir dalam sosiopsikologis sastra adalah sikap penyair terhadap corak kehidupan sosial masyarakat dalam puisinya misalnya sikap keikhlasan, masa bodoh, tidak setuju serta berbagai macam sikap sesuai dengan kompleksitas pikiran penyair itu sendiri. Ketiga unsur sosiopsikologis sastra harus terpenuhi untuk mendapatkan gambaran yang utuh dari cipta puisi.

Berdasarkan hasil analisis tersebut dapat disimpulkan bahwa ketiga unsur sosiopsikologis sastra dalam puisi memiliki peranan penting bagi pembaca. Peranan ketiga unsur tersebut adalah memudahkan pembaca dalam memahami dan dapat merasakan langsung apa yang disampaikan oleh penyair lwat puisinya serta amanat yang terkandung dalam sebuah puisi. 


\section{SIMPULAN}

Berdasarkan hasil penelitian data dan pembahasan yang sudah dilakukan, maka dapat disimpulkan bahwa terdapat unsur sosiopsikologis dalam kumpulan puisi Doa untuk Anak Cucu karya W.S Rendra. Pada kumpulan puisi tersebut terdapat 10 puisi yang diteliti dan mendeskripsikan unsur sosiopsikologis yang meliputi hubungan antara kehidupan sosial masyarakat dengan gagasan dalam puisi, unsur kehidupan sosial masyarakat dalam puisi serta sikap penyair terhadap corak kehidupan sosial dalam puisi. Puisi tersebut antara lain "Inilah Saatnya, Kesaksiaan tentng Mastodon-mastodon, Sajak Bulan Mei 1998 di Indonesia, Ibu di atas Debu, Pertanyaan Penting, Politisi itu Adalah, He, Remco, Kesaksian Akhir Abad, Sagu Ambon, Dimana Kmu, De 'Na?, Maskumambang”.

\section{DAFTAR PUSTAKA}

Aminuddin. (2013). Pengantar Apresiasi Karya Sastra. Bandung: Sinar Baru Algensindo.

Ratna, Nyoman Kutha. (2010). Metodologi Peneltian: Kajian Budaya dan Ilmu Sosial Humaniora pada Umumnya. Yogyakarta: Pustaka Pelajar.

Rendra, W.S. (2016). Doa untuk Anak Cucu. Yogyakarta: Bentang Pustaka.

Siswantoro. (2010). Metode Peneltian Sastra. Yogyakarta: Pustaka Pelajar.

Sugiyono. (2015). Metode Penelitian Pendidikan. Bandung: Alfabeta.

Suryabrata, Sumadi. (2015). Metode Penelitian. Jakarta: Raja Grafindo Persada.

Wardani, Nugraheni Eko. (2009). Makna Totalitas dalam Karya Sastra. Surakarta: Lembaga Pengembangan Pendidikan (LPP). 